\title{
Microcephaly in infants, Ceará State, Brazil, 2015-2016
}

\section{Microcefalia em recém-nascidos, Ceará, Brasil, 2015-2016}

Luciano Pamplona de Góes Cavalcanti ${ }^{1}$. Erlane Marques Ribeiro ${ }^{2}$. André Luis Santos Pessoa ${ }^{3}$. Francisco Herlânio Costa Carvalho ${ }^{4}$. Manoel Martins Neto $^{5}$. Fernanda Montenegro de Carvalho Araújo ${ }^{6}$. Carlos Henrique Alencar ${ }^{7}$. Daniele Rocha Queiroz Lemos ${ }^{8}$. Thayse Elaine Costa Figueiredo ${ }^{9}$. Rhaquel de Morais Alves Barbosa Oliveira ${ }^{10}$. Francisca Kalline de Almeida Barreto ${ }^{11}$. Jorg Heukelbach ${ }^{12}$.

\begin{abstract}
1 Doutor em Ciências Médicas pela Universidade Federal do Ceará (UFC), Professor do Departamento de Saúde Comunitária da UFC, Fortaleza, Ceará, Brasil. 2 Doutora em Ciências da Saúde pela Universidade Federal do Rio Grande do Norte (UFRN), médica geneticista do Hospital Infantil Albert Sabin, Professora do Curso de Medicina do Centro Universitário Christus (UNICHRISTUS), Fortaleza, Ceará, Brasil. 3 Doutorando no Departamento de Neurologia do Hospital das Clínicas da Faculdade de Medicina da Universidade de São Paulo (USP), médico Neurologista Pediátrico do Hospital Infantil Albert Sabin, professor do curso de Medicina da Universidade Estadual do Ceará (UECE), Fortaleza, Ceará, Brasil. 4 Doutor em Medicina pela Universidade Federal de São Paulo (UNIFESP), Professor do Departamento de Saúde Materno Infantil da UFC, Fortaleza, Ceará, Brasil. 5 Doutorando em Saúde Coletiva pela UFC, professor do curso de Medicina da UECE, Fortaleza, Ceará, Brasil. 6 Doutora em Ciências Médicas pela UFC, virologista do Laboratório Central de Saúde Pública do Ceará (Lacen-CE), Fortaleza, Ceará, Brasil. 7 Doutor em Saúde Coletiva pela UFC, Professor do Departamento de Saúde Comunitária da UFC, Fortaleza, Ceará, Brasil. 8 Doutorado em Saúde Coletiva pela UECE, Professora da UNICHRISTUS, Fortaleza, Ceará, Brasil. 9 Estudante da UNICHRISTUS, Fortaleza, Ceará, Brasil. 10 Doutoranda em Saúde Coletiva pela UFC, enfermeira assistencial da Maternidade Escola Assis Chateaubriand (MEAC-UFC), Fortaleza, Ceará, Brasil. 11 Doutoranda em Saúde Coletiva pela UFC, Fortaleza, Ceará, Brasil. 12 Doutorado em Farmacologia pela Universidade de Aachen, Alemanha, Professor do Departamento de Saúde Comunitária da UFC, Fortaleza, Ceará, Brasil.
\end{abstract}

\section{ABSTRACT}

In late 2015, the Brazilian Ministry of Health officially announced the association between microcephaly in infants and Zika virus infection of the mother during pregnancy. We describe preliminary findings of this outbreak in Ceará, Northeast Brazil and it's clinical characteristics in each medical speciality. We report epidemiological findings of 317 cases of microcephaly outbreak potentially associated with ZIKV infection in Ceará, State, Brazil. From mid-2015 to the end of June of 2016, a total of 417 cases of microcephaly were suspected, with 317 confirmed. Among those reported cases, 83.2\% (347/417) were detected in the postpartum. Rash during pregnancy was reported by $(29.6 \%)$ of pregnant women, most commonly in the 1 st trimester $(18.4 \%)$. The proportion of microcephaly cases increased from less than $1 \%$ to $25.8 \%$ of the registered cases of genetic abnormalities. The prevalence increased from $0.06 / 1000$ live births in 2010 to 0.56 in 2015 and to 3.22 in January and February of 2016. In addition to microcephaly other associated malformations were detected, such as arthrogryposis, hyperexcitability, irritability with strong and frequent crying. The microcephaly phenotype caused by the zika virus is different from other congenital conditions. The infection in the prenatal period is a new teratogen reported. There is a predominance of neurological impairment, in which neuroimaging plays a crucial role in confirming the clinical suspicion of Congenital Zika Syndrome.

Keywords: Congenital Zika Syndrome. Microcephaly. Congenital abnormalities. Zika virus infection.

\section{RESUMO}

No final de 2015 o Ministério da Saúde do Brasil confirmou a associação entre microcefalia em bebês e infecção por vírus Zika durante a gestação. Descrevemos os achados preliminares deste surto no Ceará, Nordeste do Brasil e suas características clínicas em cada especialidade médica. Relatamos os achados epidemiológicos de 317 casos de microcefalia potencialmente associados à infecção por ZIKV no Ceará, Brasil. De meados de 2015 até o final de junho de 2016, um total de 417 casos de microcefalia foram suspeitos, com 317 confirmados. Entre os casos relatados, 83,2\% (347/417) foram detectados no pós-parto. Rash durante a gravidez foi relatado por (29,6\%) das gestantes, mais comumente no $1^{\circ}$ trimestre (18,4\%). A proporção de casos notificados de microcefalia aumentou de menos de $1 \%$ para $25,8 \%$ dos casos registrados de anormalidades genéticas. A prevalência aumentou de 0,06/1000 nascidos vivos em 2010 para 0,56 em 2015 e para 3,22 em janeiro e fevereiro de 2016. Além da microcefalia foram detectadas outras malformações associadas, como artrogripose, hiperexcitabilidade, irritabilidade com choro forte e frequente. O fenótipo de microcefalia causado pelo vírus zika é diferente de outras condições congênitas. A infecção no período pré-natal é um novo teratógeno relatado. Há uma predominância de comprometimento neurológico, em que a neuroimagem desempenha um papel crucial na confirmação da suspeita clínica da Síndrome de Zika Congênita.

Palavras-chave: Sindrome congênita por zika. Microcefalia. Malformações congênitas. Infecção por vírus Zika.

Corresponding Author: Luciano Pamplona de Góes Cavalcanti, Rua Professor Costa Mendes, 1608, $5^{\circ}$ andar, Rodolfo Teófilo, Fortaleza, Ceará. CEP: 60430-140. Telefone: +55 85 3366-8045. E-mail: pamplona.luciano@gmail.com

Conflict of interests: The authors have no conflicts of interest to declare.

Received: 26 Mar 2017; Revised: 26 Mar 2017; Accepted: 26 Mar 2017.

Rev Med UFC. 2017;57(1):30-35 


\section{INTRODUCTION}

Until recently, Zika virus (ZIKV) infection was unknown in most regions of the world. This changed dramatically in early 2015, after the occurrence of an outbreak originating from Brazil, which is currently spreading throughout the American continent. ${ }^{1}$ From mid-2015 to the end of November of 2016, a total of 10,441 suspected cases of microcephaly were reported from all Brazilian states, with most of them occurring in the Northeast of the country. ${ }^{2-5}$ In late 2015, the Brazilian Ministry of Health officially announced the association between microcephaly in infants and Zika virus infection of the mother during pregnancy. ${ }^{6}$ In fact, a recent review of available evidence concluded that there is a causal relationship between prenatal Zika infection and microcephaly. ${ }^{7,8}$

Here we describe the epidemiological and clinical characteristics of cases of microcephaly which occurred during the current outbreak in the state of Ceará in Northeast Brazil (Figure 1). We describe preliminary findings of this outbreak in Ceará. In addition, we describe this outbreak and its clinical characteristics in each medical speciality.

Figure 1. Map with suspected cases of microcephaly associated with ZIKV in Ceará between October 2015 and March 2016.

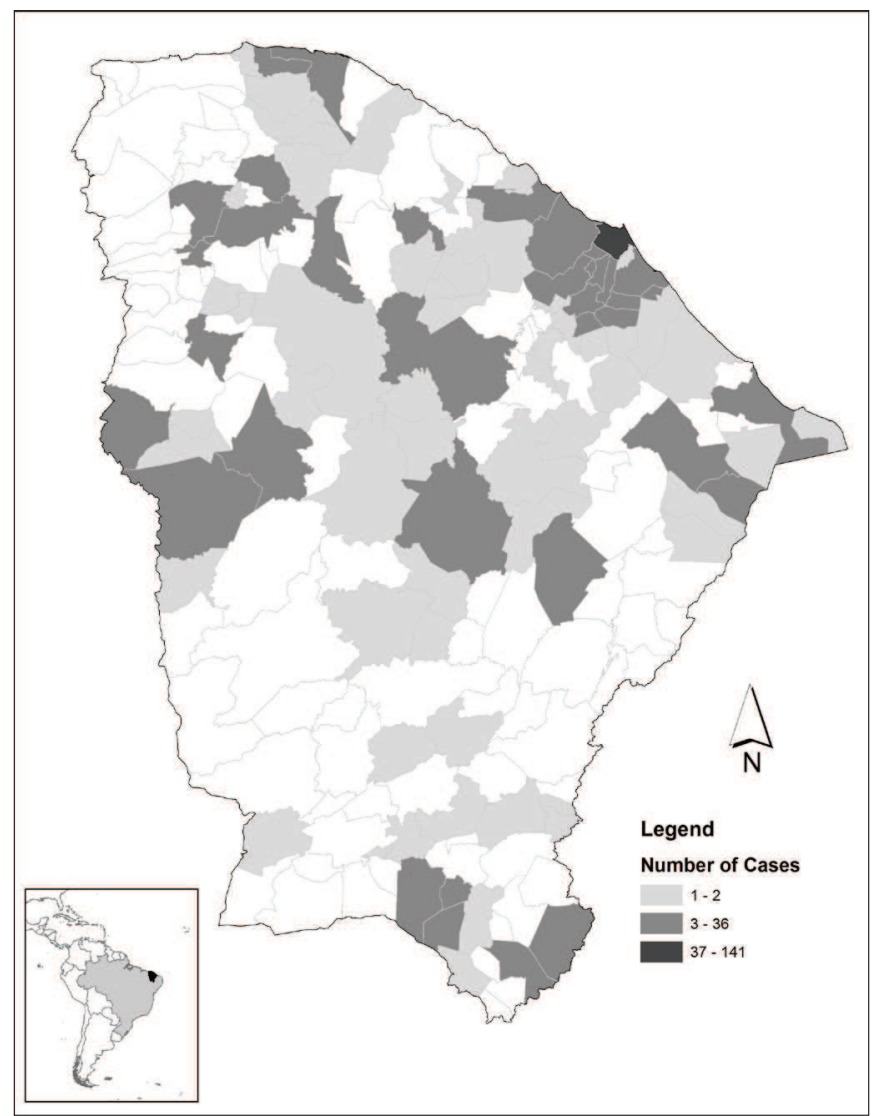

\section{THE STUDY}

This was a retrospective study of microcephaly outbreak potentially associated with ZIKV infection in Ceará, northeastern Brazil. Field investigations and the collection of samples between June 2015 and March 2016 were reported to the Public Health Authority (SESA-CE) (Graphic 1). This review was conducted under the public health authority of Ceará, Brazil.

According to World Health Organization (WHO) and Ministry of Health of Brazil (MS), microcephaly is characterized by the measurement of the skull performed at least 24 hours after birth and within the first week of life (up to 6 days and 23 hours), using standard equipment, where the Cephalic Perimeter (PC) is less than two (-2) standard deviations below the specific mean for sex and gestational age., ${ }^{9,10}$

\section{Newborn with microcephaly}

Newborn with less than 37 weeks gestational age, with measurement of cephalic perimeter less than -2 standard deviations according to table Intergrowth, for age pregnancy and sex. Newborn with 37 or more weeks of gestation, with measurement of cephalic perimeter less than or equal to 31.5 $\mathrm{cm}$ for girls and 31.9 for boys, equivalent to less than -2 standard deviations for the age of the neonate and sex.

\section{Stillborn suggestive of congenital infection}

Pregnant stillbirth with clinical suspicion and/or laboratory results consistent with acute rash illness during pregnancy, with: measurement of smaller head circumference than or equal to -2 standard deviations for gestational age and sex, according to 
Graphic 1. Number of reported cases of microcephaly\# in full-term newborns following laboratory-confirmed Zika virus transmission in Ceará, Brazil, 2015 and 2016.

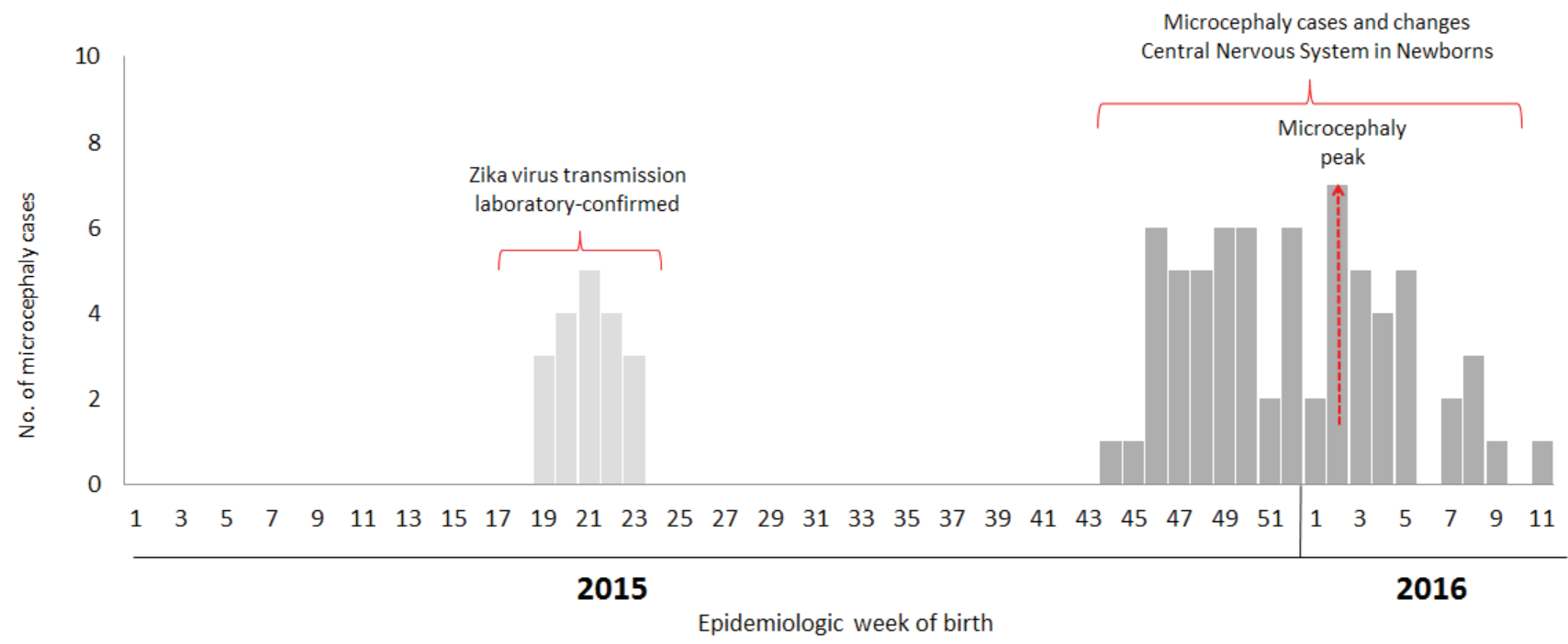

\# Defined as head circumference $\geq 3$ standard deviations below the mean for age and sex.

table Intergrowth where possible be measured OR presenting congenital anomalies of the Central Nervous System (CNS), such as iniencephaly, encephalocele, closed spina bifida, open spina bifida, anencephaly or cranioraquisquise, and serious structural defects, such as multiple arthrogryposis congenita.

\section{Fetus with alterations of the central nervous system during pregnancy}

Present at least one of the following criteria relating to changes in the central nervous system, identified in sonographic examination: presence of cerebral calcifications and/or ventricular changes and/or at least two of the following signs of posterior fossa abnormalities (cerebellar hypoplasia, hypoplasia of the cerebellar vermis, enlargement of the posterior fossa greater than $10 \mathrm{~mm}$ and agenesis/hypoplasia of the corpus callosum).

\section{Abortion suggestive of congenital infection}

Pregnant abortion with clinical suspicion and/or laboratory results consistent with acute rash illness during pregnancy.

Our routine protocol for reviewing suspected microcephaly possibly associated with ZIKV involved collecting data on maternal and infants. The confirmed cases of microcephaly presented negative results for toxoplasmosis, rubella, cytomegalovirus, syphilis and HIV serologies. Brain imaging for computed tomography (CT), consultation with a geneticist and imaging was performed when available. We conducted this investigation as part of routine clinical practice; but the images used were approved by human subjects.

We report epidemiological findings of the microcephaly outbreak potentially associated with ZIKV infection in Ceará.

From mid-2015 to the end of June of 2016, a total of 417 cases of microcephaly were suspected, with 317 confirmed (Graphic 1).
Among those reported cases, 83.2\% (347/417) were detected in the postpartum and $16.8 \%(70 / 417)$ during pregnancy. Rash during pregnancy was reported by $(29.6 \%)$ of pregnant women, most commonly in the $1^{\text {st }}$ trimester $(18.4 \%)$.

Twenty-eight infant deaths were reported, 4 in stillbirths and 24 in the postpartum period. Of these, in 8 cases ZIKA virus was identified in fetal tissue.

The number of microcephaly cases in 2015/2016 indicates a considerable increase as compared to previous years. From 2010 to 2014 there were in average 7 microcephaly cases and 127.549 births annually (Table 1). In contrast, in 2015, there were 72 cases and from January to February of 2016, there were 46 cases of microcephaly. The proportion of microcephaly cases increased from less than $1 \%$ to $25.8 \%$ of the registered cases of genetic abnormalities (Table 1). The prevalence increased from $0.06 / 1000$ live births in 2010 to 0.56 in 2015 and to 3.22 in January and February of 2016 (Table 1).

Our findings show that patients affected by congenital zika syndrome must have microcephaly with craniofacial disproportion with predominance of face (Figure 2). Some features may accompany this picture, especially in severe cases as the excess of skin on the scalp, forming folds that reduce with increasing age; occipital protuberance, which in severe cases is palpable. On the face there may be excess skin on the forehead, temporal narrowing trigonocephaly, thin upper lip and retromicrognatia. The short neck and an excess of skin in the neck are often reported in our casuistry. We also recorded the frequent presence of pits in elbows and knees.

After the neurological physical examination our cases are characterized by neurological abnormalities noted since the first month of life, Moro exacerbated and tremors of extremities; early pyramidal signs such as hyperreflexia, decreased strength and spastic hypertonia in the limbs. Joint contractures and some cases of arthrogryposis are also 
Table 1. Congenital anomalies occurred in Ceará between 2010 and 2016 *.

\begin{tabular}{|c|c|c|c|c|c|c|c|c|c|}
\hline \multirow[t]{2}{*}{$\begin{array}{c}\text { Live birth } \\
\text { data in Ceará }\end{array}$} & \multicolumn{2}{|c|}{2010} & 2011 & 2012 & 2013 & 2014 & $2015^{\&}$ & $\begin{array}{c}\text { (Jan-Fev) } \\
\text { 2016 }^{\&}\end{array}$ & \multirow{2}{*}{$\begin{array}{c}\begin{array}{c}\text { Med } \\
(2010 \text { a 2014) }\end{array} \\
\text { N (\%) Prev.* } \\
\end{array}$} \\
\hline & N (\%) & Prev.* & N (\%) Prev.* & N (\%) Prev.* & N (\%) Prev.* & N (\%) Prev.* & N (\%) Prev.* & N (\%) Prev.* & \\
\hline Total live births & 128.8 & & 128.589 & 126.866 & 124.874 & 128.587 & 129.578 & 14.290 & 127.549 \\
\hline $\begin{array}{l}\text { Live births } \\
\text { with congenital } \\
\text { anomalies }\end{array}$ & 997 & & 959 & 956 & 974 & 919 & 1.072 & 178 & 961 \\
\hline $\begin{array}{l}\text { Live births with } \\
\text { microcephaly }\end{array}$ & $8(0,8)$ & 0,62 & $4(0,4) \quad 0,31$ & $10(1,0) \quad 0,79$ & $5(0,5) \quad 0,40$ & $7(0,7) \quad 0,54$ & $72(6,7) \quad 5,56$ & $46(25,8) \quad 32,19$ & $7(0,7) \quad 0,53$ \\
\hline $\begin{array}{c}\text { Congenital } \\
\text { malformation of } \\
\text { the circulatory } \\
\text { system }\end{array}$ & $31(3,1)$ & 2,41 & $30(3,1) \quad 2,33$ & $36(3,7) \quad 2,84$ & $28(2,8) \quad 2,24$ & $36(3,9) \quad 2,80$ & $62(5,8) \quad 4,78$ & $6(3,4) \quad 4,20$ & $32(3,4) \quad 2,52$ \\
\hline $\begin{array}{l}\text { Lip cleft and } \\
\text { cleft palate }\end{array}$ & $60(6,1)$ & 0,47 & $68(7,1) \quad 0,53$ & $66(6,9) \quad 0,52$ & $69(7,1) \quad 0,55$ & $72(7,8) \quad 0,56$ & $57(5,3) \quad 0,44$ & $6(3,4) \quad 0,42$ & $67(7,0) \quad 0,53$ \\
\hline $\begin{array}{l}\text { Congenital hip } \\
\text { deformities }\end{array}$ & $11(1,1)$ & 0,85 & $4(0,4) \quad 0,31$ & $3(0,3) \quad 0,24$ & $4(0,4) \quad 0,32$ & $2(0,2) \quad 0,16$ & $5(0,5) \quad 0,39$ & $0(0,0) \quad 0,00$ & $5(0,5) \quad 0,38$ \\
\hline $\begin{array}{l}\text { Congenital } \\
\text { deformities of } 1 \\
\text { the feet }\end{array}$ & $190(19,1)$ & 14,75 & $156(16,3) \quad 12,13$ & $171(17,9) \quad 13,48$ & $180(18,5) \quad 14,41$ & $171(18,6) \quad 13,30$ & $147(13,7) \quad 11,34$ & $21(11,8) \quad 14,70$ & $174(18,1) \quad 13,61$ \\
\hline $\begin{array}{c}\text { Other } \\
\text { congenital } \\
\text { anomalies }\end{array}$ & $697(69,9)$ & 54,10 & $697(72,7) \quad 54,20$ & $670(70,1) \quad 52,81$ & $688(70,6) \quad 55,10$ & $631(68,6) \quad 49,07$ & $729(68,0) \quad 56,26$ & $99(55,6) \quad 69,28$ & $677(70,4) \quad 53,05$ \\
\hline
\end{tabular}

\& Data not closed.

* Prevalence for every 10,000 live births.

Figure 2. Microcephaly in children born alive in the State of Ceará, Brazil.

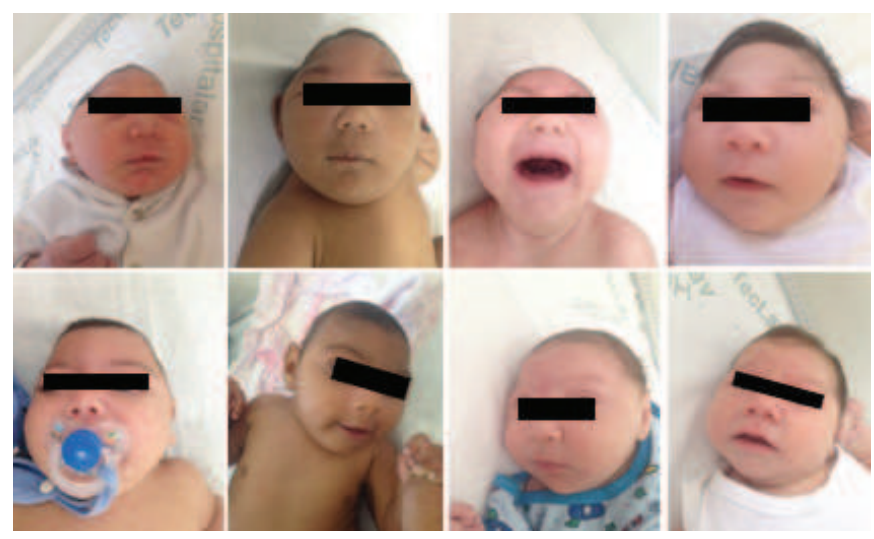

common, especially in the joints of lower limbs such as hips, knees and ankles, but also to a lesser degree on the shoulders, elbows and wrists. Some children had dysphagia, which can lead to death from aspiration pneumonia.

From a neuroradiological point of view, the most frequent findings are: predominantly subcortical cerebral calcifications but also being found in the nuclei of the base. Such calcifications often appear almost contiguous with if they were bands. Reduction of cortical thickness and also important subcortical with the consequent ventricular dilatations ex-vacuum and subarachnoid space. It has also been shown compatible with polymicrogyria, cortical pattern characterized by excessive number of small turns separated by shallow grooves. This formation is developed between the 18 th and 27 th gestational weeks due to imbalance of growth between the supra and infranugranular layers. Was also found encashment of the sutures of the posterior bones of the skull.

\section{Ultra-sonographic findings of pregnant women and fetuses infected with ZIKA}

No fetal injury notification was carried out in the first quarter, as reported by Oliveira. ${ }^{11}$ Among symptomatic women: fever, itching or rash were reported mainly in the first trimester of pregnancy. However, about onethird of pregnant women did not refer to this clinical picture. The main fetal anatomic changes described were microcephaly - light (head circumference 2 to 3 standard deviations below the mean for gestational age) or severe (smaller head circumference than 3 standard deviations below the mean for gestational age); cerebral calcifications periventricular or parenchymal and cerebellum; Intraocular calcifications, thymus and liver; dilation of the lateral ventricles, enlargement of the posterior fossa and increased subarachnoid space (Figure 3). 
Figure 3. Ultrasonographic findings in fetuses supposedly infected by ZIKV. (A) and (B) scattered calcifications by cerebral parenchyma associated with ventriculomegaly. (C) Calcifications of the cerebellum associated with enlargement of the posterior fossa. (D) Calcifications of thalamus.

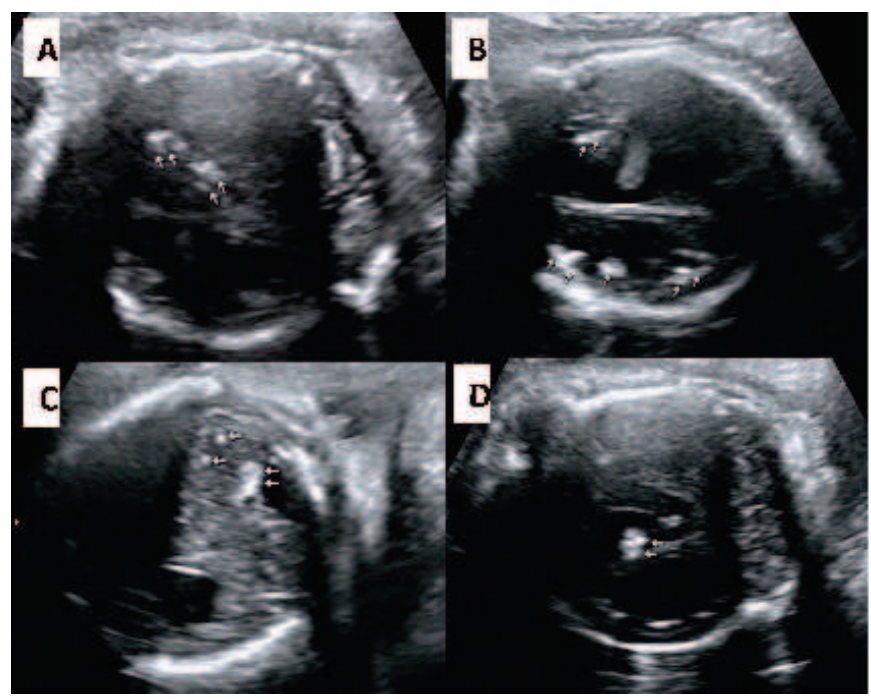

Among our sample, we also find fetal growth restriction, arthrogryposis, clubfoot, hepatomegaly, calcification of the aortic and mitral valves, hyperflexion of the fingers, nuchal fold thickening, oligohydramnios and polyhydramnios. In the cases that it was possible to perform the Doppler in the umbilical artery and fetal vessels (middle cerebral artery) all were normal. There has been described a case of placental insufficiency in cases of fetal growth restriction or oligohydramnios.

\section{Description and image of the neurological findings}

When it was possible a complete neurological evaluation the neurological clinical spectrum ranged from normal development to neurological changes, being more frequent: hyperexcitability with jolts to stimuli, uncontrollable crying, irritability, exacerbated Moro reflex and tremors in the extremities; early pyramidal signs such as hyperreflexia, decreased strength and stiffness in spastic limbs; extrapyramidal signs as appendicular dystonia rest and action as well as tremors.

The presence of arthrogryposis was common among patients, especially in the joints of the lower limbs such as hips, knees and ankles and to a lesser extent on the shoulders, elbows and wrists.

Despite the severe brain damage found in the majority of patients evaluated, the incidence of convulsions has been very uncommon to date, as well as electroencephalographic changes.

The most common neuroradiologic aspects found there were predominantly pericortical cerebral calcifications, but also could be found in the basal ganglia and periventricular. These calcifications often present themselves almost contiguously as if they were bands. Cortical or subcortical atrophy are usually important with consequent ventricular dilatation former vacuum and subarachnoid space. It was also frequently found brain with bump the sutures of the posterior skull bone (Figure 4).

Figure 4. Cranial tomography image without contrast. Findings: Pericortical calcifications, cortico-subcortical atrophy with ex-ventricular dilation and subarachnoid space. Simplification of turns.

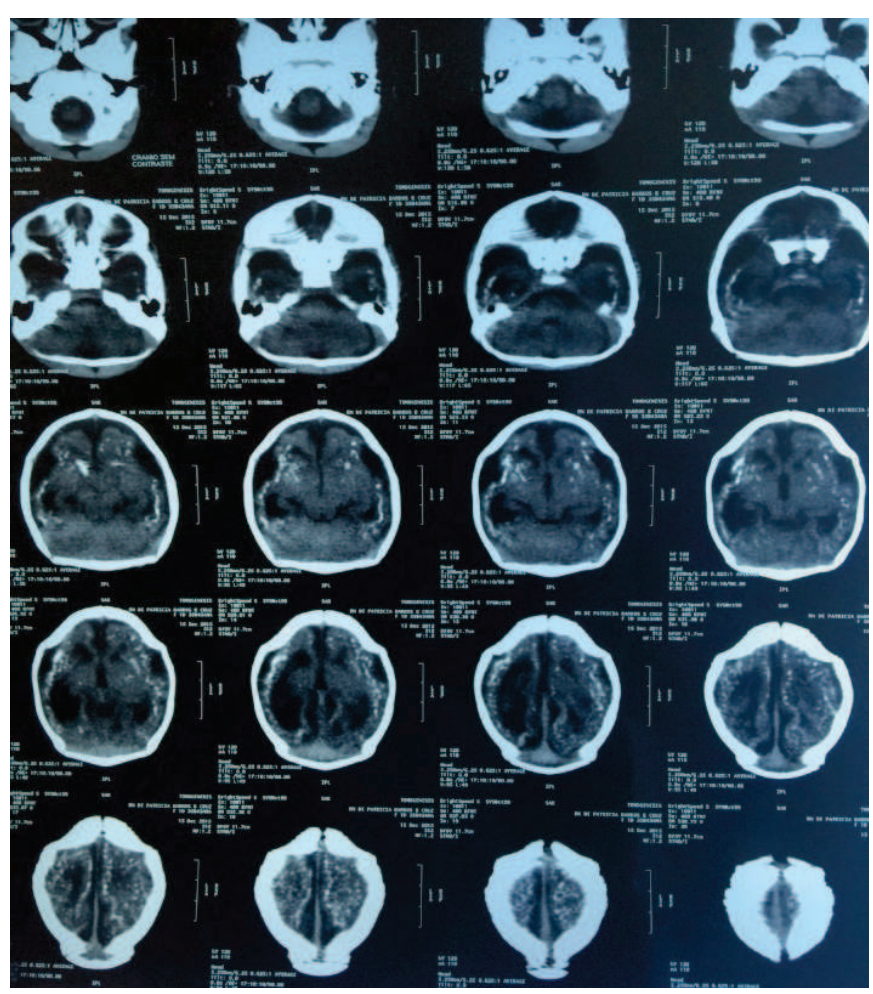

\section{CONCLUSIONS}

We report the occurrence and 317 cases of microcephaly in the State of Ceará, Northeast Brazil. In addition to impairment of the cephalic perimeter, other associated malformations, such as arthrogryposis, hyperexcitability, irritability with strong and frequent crying were detected. 28 deaths were confirmed. In our outbreak we detected the main clinical signs described in the world literature. ${ }^{12}$ In milder forms we have children who were born with a normal head circumference and few or no orthopedic deformity. ${ }^{13}$ The microcephaly phenotype caused by zika virus is different from other congenital conditions. The infection in the prenatal period is a new teratogen reported. There is a predominance of neurological impairment, in which neuroimaging plays a crucial role in confirming the clinical suspicion of Congenital Zika Syndrome. ${ }^{14}$

Thus, a great challenge for the public health of Brazil and in the world is established. Challenges ranging from the discovery and confirmation of the potential forms of transmission of the disease, through timely diagnosis, appropriate treatment and management of children, rehabilitation of children with sequelae, psychological support for families and production of vaccines. 


\section{REFERENCES}

1. Heukelbach J, Alencar CH, Kelvin AA, De Oliveira WK, Pamplona de Góes Cavalcanti L. Zika virus outbreak in Brazil. J Infect Dev Ctries. 2016;10(2):116-20.

2. Campos GS, Bandeira AC, Sardi SI (2015) Zika virus outbreak, Bahia, Brazil. Emerg Infect Dis.2015;21(10):1885-6.

3. Cardoso CW, Paploski IA, Kikuti M, Rodrigues MS, Silva MM, Campos GS, et al. Outbreak of exanthematous illness associated with Zika, chikungunya, and dengue viruses, Salvador, Brazil. Emerg Infect Dis. 2015;21(12):2274-6.

4. Zanluca C, Melo VC, Mosimann AL, Santos GI, Santos CN, Luz K. First report of autochthonous transmission of Zika virus in Brazil. Mem Inst Oswaldo Cruz. 2015;110(4):569-72.

5. Kleber de Oliveira W, Cortez-Escalante J, De Oliveira WT, do Carmo GM, Henriques CM, Coelho GE, et al. Increase in reported prevalence of microcephaly in infants born to women living in areas with confirmed Zika virus transmission during the first trimester of pregnancy - Brazil, 2015. MMWR Morb Mortal Wkly Rep. 2016;65(9):242-7.

6. Brasil. Ministério da Saúde. Informe epidemiológico: Monitoramento dos casos de microcefalia no Brasil [Internet]. Brasília; 2016 [cited 2016 Mar 31]. Available from: http://portalsaude. saude.gov.br/ images/pdf/2016/ marco/30/COES-Microcefalias--Informe-Epidemiol--gico-19--SE-12-2016--29mar2016--08h50.pdf

7. Rasmussen SA, Jamieson DJ, Honein MA, Peterson LR. Zika virus and birth defects - reviewing the evidence for causality. N Engl J Med. 2016;374(20):1981-7.

8. Brasil P, Pereira JP Jr, Raja Gabaglia C, Ribeiro Nogueira RM, Damasceno L, Wakimoto M, et al. Zika virus infection in pregnant women in Rio de Janeiro - preliminary report. N Engl J Med. 2016;375(24):2321-34.
9. World Health Organization. Assessment of infants with microcephaly in the context of Zika virus-Interim Guidance-4 March 2016 [Internet]. Genebra; 2016 [cited 2016 Mar 31]. Available from: http://apps.who.int/iris/bitstream/10665/204475/1/WHO_ZIKV_ MOC_16.3_eng.pdf?ua $=1$

10. Secretaria de Saúde do Estado do Ceará. Protocolo de vigilância e resposta à ocorrência de microcefalia e malformações congênitas relacionadas a infecções perinatais [Internet]. Fortaleza; 2016 [cited 2016 Abr 20]. Available from: http://www.saude.ce.gov. $\mathrm{br} /$ index.php/protocolos-de-tratamento?download $=2285 \% 3 \mathrm{Apr}$ otocolo-de-vigilancia-e-resposta-a-ocorrencia-de-microcefaliae-malformacoes-congenitas-relacionadas-a-infeccoes-perinatais Portuguese.

11. Oliveira Melo AS, Malinger G, Ximenes R, Szejnfeld PO, Alves Sampaio S, Bispo de Filippis AM. Zika virus intrauterine infection causes fetal brain abnormality and microcephaly: tip of the iceberg? Ultrasound Obstet Gynecol. 2016;47(1):6-7.

12. Moore CA, Stapls JE, Dobyns WB, Pessoa A, Ventura CV, Fonseca EB, et al. Characterizing the pattern of anomalies in congenital Zika syndrome for pediatric clinicians. JAMA Pediatr. 2017;171(3):288-95.

13. Van der Linden V, Pessoa A, Dobyns W, Barkovich AJ, van der Linden H Jr, Rolim EL Filho, et al. Description of 13 Infants Born During October 2015-January 2016 With Congenital Zika Virus Infection Without Microcephaly at Birth - Brazil. MMWR Morb Mortal Wkly Rep. 2016;65(47):1343-48.

14. Ribeiro EM, Lopes TF, Kerbage SC, Pessoa AL, Cavalcanti LP. From the perception of a cluster of cases of children with microcephaly to congenital Zika syndrome in Brazil: the lessons we have learned and the challenges that lie ahead of us. Journal of Venomous Animals and Toxins including Tropical Diseases. J Venom Anim Toxins Incl Trop Dis. 2017;23:15.

\section{Como citar:}

Cavalcanti LP, Ribeiro EM, Pessoa AL, Carvalho FH, Martins M Neto, Araújo FM, et al. Microcephaly in Infants, Ceará State, Brazil, $2015-2016$. Rev Med UFC. 2017 jan-abr;57(1):30-35. 